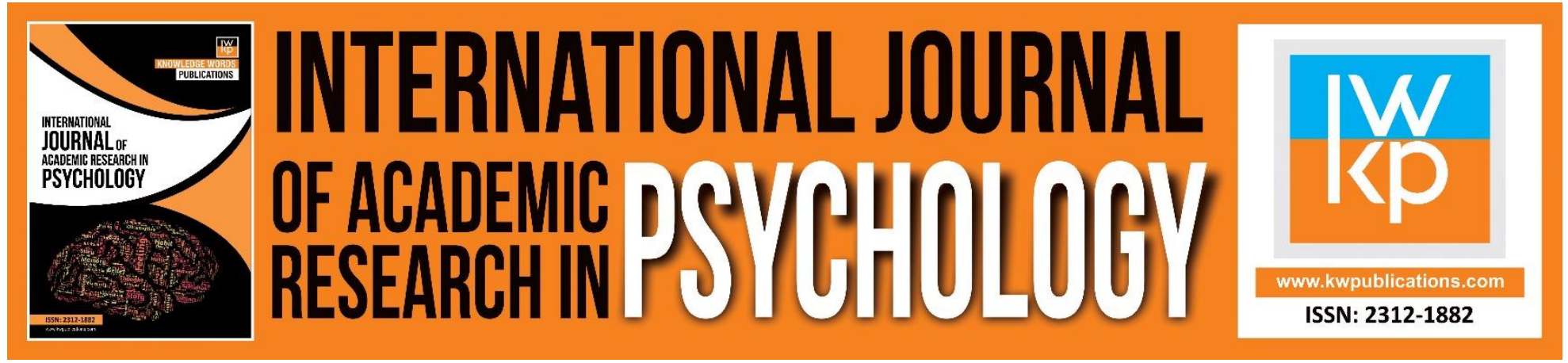

\title{
The Psychological Problems Faced by Students during General Secondary Education Certificate Examinations in Jordan
}

Maen Hani Al-Amryeen, Nashaat Abdelaziz Baioumy, Abdul Wahid Bin Salieh

To Link this Article: http://dx.doi.org/10.46886/IJARP/v7-i1/7121

DOI:10.46886/IJARP/v7-i1/7121

Received: 07 January 2020, Revised: 23 February 2020, Accepted: 16 March 2020

Published Online: 30 March 2020

In-Text Citation: (Al-Amryeen et al., 2020)

To Cite this Article: Al-Amryeen, M. H., Baioumy, N. A., \& Salieh, A. W. Bin. (2020). The Psychological Problems Faced by Students during General Secondary Education Certificate Examinations in Jordan. International Journal of Academic Research in Psychology, 7(1), 1-16.

Copyright: (C) 2020 The Author(s)

Published by Knowledge Words Publications (www.kwpublications.com)

This article is published under the Creative Commons Attribution (CC BY 4.0) license. Anyone may reproduce, distribute, translate and create derivative works of this article (for both commercial and non-commercial purposes), subject to full attribution to the original publication and authors. The full terms of this license may be seen at: http://creativecommons.org/licences/by/4.0/legalcode

Vol. 7, No. 1, 2020, Pg. 1 - 16

https://kwpublications.com/journals/journaldetail/IJARP

JOURNAL HOMEPAGE

Full Terms \& Conditions of access and use can be found at https://kwpublications.com/pages/detail/publication-ethics 


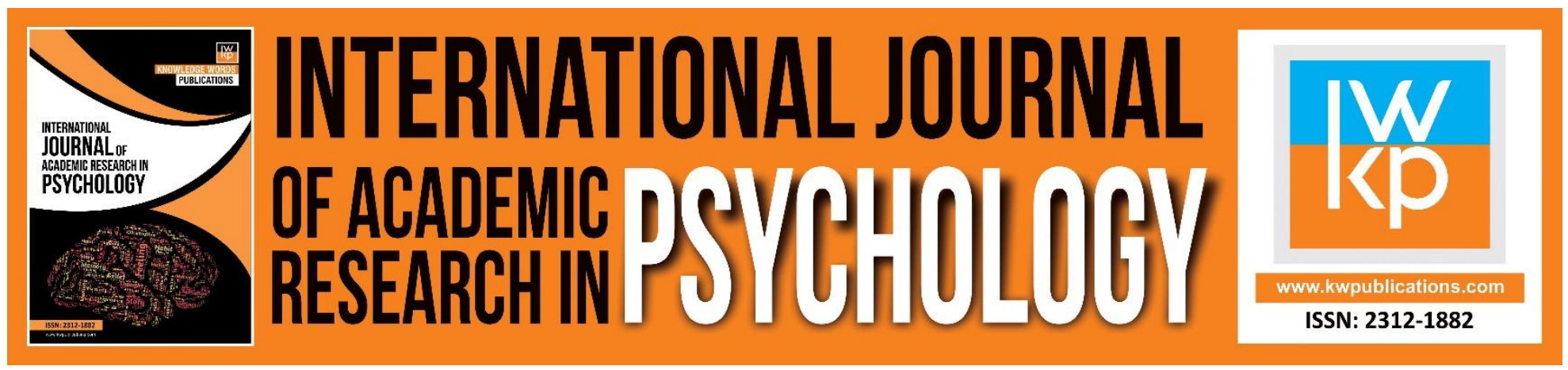

\title{
The Psychological Problems Faced by Students during General Secondary Education Certificate Examinations in Jordan
}

\author{
Maen Hani Al-Amryeen, Nashaat Abdelaziz Baioumy, Abdul Wahid \\ Bin Salieh
}

Faculty of Islamic Contemporary Studies, University Sultan Zainl Abidin, Terengganu, Malaysia

\begin{abstract}
The study aimed to analyze the impact of tests on psychological problems facing public high school students in Jordan, and due to the tests know the impact on psychological problems. The study adopted a descriptive-analytical approach to obtain the results. The study population consisted of all students enrolled in the public secondary stage in Tafila Governorate for the academic year 2019/2020 AD, the number of which was 2025 male and female students. The study sample consisted of (364) male and female students chosen in a cluster-randomized method, which formed (17.9\%) of the original study community. The researcher sought to analyze the impact of tests on psychological problems facing public high school students in Jordan through a questionnaire that included three dimensions, namely: The first dimension: study problems; the second dimension: behavioral problems; and the third dimension: personal problems, where the scale included (30) items for students, its validity and reliability were verified. The most important results of the study that was shown by the study were: that the tests affected the psychological problems of public high school students in the governorate of Jordan. The study also showed differences of statistical significance at the level of significance $(\alpha<0.05)$ in the impact of the tests on psychological problems according to the gender variable and favour of females. The results also showed that the arithmetic mean of psychological problems among students at the public secondary stage in Tafila Governorate came as average and with average arithmetic (3.57) and a standard deviation (0.28). The study recommended activating the counseling programs that reduce psychological problems for public high school students.
\end{abstract}

Keywords: Tests, Psychological Problems, Public High School, Jordan.

\section{Introduction}

The subject of the tests occupied an important position in educational and psychological studies because it causes psychological problems for students in their various stages of development. In the educational field, the sooner the date of the tests approaches, students show a set of physiological 
and psychological symptoms that were not apparent before the test period. The test is the primary concern of the student and family. The atmosphere becomes fraught with stress and anxiety, and even the majority of families mobilize all members of the family including the student. The psychological condition that accompanies the student when performing the test negatively affects the different mental processes needed during the performance of the test. Psychological problems often increase among high school students if they realize that their fate in the exam is success or failure which means a lot to prove their existence or self-realization. Among what causes many psychological problems for them is that the exam result decides whether or not they will enter universities and colleges. The mark they receive determines the type of specialization they choose in light of the intense competition they face from the peers of high school graduates. In addition to the parents' desire to obtain higher education and enter certain specialties according to their desire and aspirations, the fear and anxiety among many students causes sudden illness as well as sudden events that negatively affect their results (Saada et al., 2004). All these call for the need to carry out such a study, and as such, the current study aims to reveal the impact of tests on psychological problems faced by public high school students in Jordan.

\section{Questions of the Study}

1. What is the level of psychological problems of public high school students?

2. What is the effect of the tests on psychological problems of public high school students in Tafila Governorate?

3. Are there statistically significant differences at the level of significance $(\alpha<0.05)$ in the level of psychological problems attributable to the variable (gender)?

\section{Objectives of the Study}

The study aims to achieve the following goals:

Determine the most common level of psychological problems among the study sample individuals.

Know the effect of psychological problems because of the tests.

Check for differences in psychological problems due to gender and the tests of the study sample individuals.

\section{The Importance of the Study}

1. Theoretical importance: The importance of this study lies in the fact that it highlights an educational stage of great interest in Jordanian society, where the secondary stage is considered a crucial stage for what the student has acquired in the school years, and a stage that determines future choices. It is also a survey and follow-up phase from the family than usual. It is well known that the specific standard for all is the test, and as such, the study of the psychological problems caused by the test is essential.

2. Applied importance: The importance of the study is centered on the importance of the nature of the target group, which are public high school students, since the public secondary stage affected most of the components in the society, including students and families. This gives an applied importance to this study in identifying and characterizing the problems of this group by helping them to care for what is beneficial to the pedagogical and educational process. It 
INTERNATIONAL JOURNAL OF ACADEMIC RESEARCH IN PSYCHOLOGY

Vol. 7, No. 1, 2020, E-ISSN: 2312-1882 @ 2020 KWP

is also expected that the study will help in identifying the problems related to this category, which will contribute to reducing the sleeplessness that negatively affects student results.

\section{Theoretical Framework}

The public secondary school certificate in Jordan comes after the student has finished all basic, middle, and secondary school classes. The Tawjihi stage is the culmination of these academic classes that the student spent in school. This stage is followed by another educational stage represented by entering the university. In Jordan, the student after completing high school has completed twelve years of schooling. At the end of this stage, the student submits a set of ministerial examinations, which are prepared by the Ministry of Education. These exams are inherently different from the nature of school exams that students used to pass in their previous semesters (Rabaabiha, 2015).

It is known that the public secondary school stage comes in conjunction with the stage of adolescence experienced by the student, as there is a set of physiological, social, and physical changes that occur to the student accompanied by a set of manifestations of growth, development, and a steady increase in physical and mental growth. During the adolescence stage, the future character that a person will be, starts to be drawn like a new birth. For this reason, all the conflicts and challenges that the student may face needs to be taken into consideration. Hence, it is incumbent to look to these students at this stage, as they are more in need of care and attention than ever before (Shuraim, 2009).

\section{Psychological Problems}

Psychological problems are individual's inability to achieve compatibility with needs that result from lack of psychological and social compatibility. Shabeer (2007) considered that individual's incompatibility with himself and environment is the main reason for psychological problems, where individual fails to achieve goals and satisfy psychological, physical and social needs. There are many disorders that the individual suffers from, including: anxiety, psychological tension, apathy, despair, pessimism, depression, mental excitement, feelings of guilt, jealousy, sensitivity, excessive hate, loss of self-confidence, and fear of the future.

\section{Types of Psychological Problems}

Zahran (2004) conducted many research on psychological problems faced by young people, including: feelings of guilt and remorse, anxiety and tension, feelings of deficiency, shame and confusion, lack of self-confidence, feelings of emptiness and loss, fear of submission and insult, fear of criticism, impulses mood, weakness and determination, irritability and ease of nervous stimulation and emotional sensitivity, constriction, lack of happiness and lack of responsibility.

\section{Causes of Psychological Problems}

There are many factors and causes that cause psychological problems. It is difficult to find a single cause for psychological problems, but they are usually many and interrelated, where the psychological problem is the outcome of many factors. They can be summarized as follows:

1. Biological Factors: These include genetics, disorders, moods, gland dysfunction factors, and metabolic processes in body cells (Rimawi, 2003).

2. Psychological Factors: they are many and interrelated, such as weak self-control, weak ability to moral judgment, exaggeration in the interpretation of aggression, psychological trauma, failure to 
INTERNATIONAL JOURNAL OF ACADEMIC RESEARCH IN PSYCHOLOGY

Vol. 7, No. 1, 2020, E-ISSN: 2312-1882 @ 2020 KWP

control emotions, insecure attachment, and negative emotions such as feeling inferior, feeling guilty, dependent, impulsive, and preparing for anxiety and depression (Rimawi, 2003).

3. Environmental Factors: it is linked to family and social factors, for example parental treatment, family disintegration, poverty, crime, unemployment, wars, and lack of guidance and counseling (El Sherbiny, 2002).

\section{The Importance of the Achievement Test}

The achievement tests are extremely important. The most prominent among them can be show in the following points (Rawashidah et al. $2000 \mathrm{CE}$ )

1. A teacher or teacher-based achievement score can enable teachers to know the student's strengths and weaknesses.

2. The ability to rely on tests to reach a measure of student's achievement, and to know their progress in the scientific and cognitive aspects.

3. The tests are based on raising the student's motivation to learn.

4. The test gives educators the ability to assess their teaching methods.

5. The test provides the student, parent, and the educators with the appropriate feedback that shows the student's achievement levels.

6. The importance of the tests increases until they reach a point where the entire achievement program can be evaluated.

\section{Specifications for Achievement Test}

There is a set of specifications that are supposed to be available in the achievement test in order to meet the need for which it was put in place, and these characteristics make the test good according to educators' perspective, and among these specifications (Rawashidah et al., 2000)

1. Truthfulness: test honesty means that the test is able to measure the ability or the thing for which it was originally set, and if the test is designed to measure the student's ability to obtain information in the science subject in the seventh grade, and able to measure that, then it is an honest test. However, if the test measures something other than that, such as measuring the student's skills in science subject, it is not an honest test.

2. Consistency: Consistency means that the relative position of the student does not change in the test when re-applying that test again, or applying another equivalent image of this test to the same group, which leads to the stability of the test results.

3. Objectivity: In this capacity, this means that the test results are not affected by the subjective side of the corrector, meaning that the subjective aspects of the corrector are neutralized while correcting the test.

4. Inclusivity: In this capacity, this test means that the exam is comprehensive in all aspects of the subject matter, including all study goals that needs to be measured in the test.

\section{Building Test}

When we talk about the test in general, we refer indirectly to the test paper, as the test paper itself is a practical application towards assessing students, and it is necessary to follow a set of scientific 
INTERNATIONAL JOURNAL OF ACADEMIC RESEARCH IN PSYCHOLOGY

Vol. 7, No. 1, 2020, E-ISSN: 2312-1882 @ $2020 \mathrm{KWP}$

and practical steps in order to build this paper in a correct and sound way, by going with the following steps (Rawashidah, 2000)

1. Determine the goal and purpose of this test, i.e. that the test clearly indicates the purpose for which it was intended.

2. Content analysis, which refers to the set of technical methods and procedures that were designed to classify the subject into main topics and then break it down into measurable goals.

3. Building a specification table, it is a chart that links the main elements of the content to the evaluation fields, and their sub-skills, and determines the relative importance of each.

\section{Literature Review}

The study of Abdel-Lawi (2012) aimed to know the relationship between psychological and behavioral problems among children of the first three years of primary school and their academic achievement in addition to knowing the difference in the average scores of each psychological problem based on the gender variable, where the study sample consisted of (300) students. The researcher used the descriptive approach. The most important results of the study were an inverse relationship between children's psychological problems and their academic achievement. It was discovered that there are no differences between male and female in psychological problems.

Rabaabiha (2015), a study titled "Academic achievement barriers for public high school students (Tawjihi) from the point of view of successful and unsuccessful students and their guardians". This study aimed to identify the obstacles related to academic achievement among high school students from the point of view of successful and unsuccessful students and their parents in the governorate of Irbid for the academic year 2014/2015 AD, and whether there were statistically significant differences in these obstacles due to gender, place of residence and the study branch. The results showed that there is an average level of obstacles related to academic achievement among the successful students compared to the unsuccessful who showed a high level of obstacles. While there were statistically significant differences in the fields of self and educational obstacles due to the variable of the study branch and for the benefit of information management students, there are no statistically significant differences in the level of obstacles as a whole due to gender and place of residence variables.

Shurab and Wadi (2015) conducted a study entitled "The sources of school stress and its relationship to the general academic achievement of high school students in the light of a number of variables". The study aimed to identify the most common sources of school stress and its relationship to the general academic achievement of secondary school students and the differences in school pressures that the target group is exposed to according to the variables (Sex, specialization, level of education of the head of the family). The research sample was chosen from the eleventh grade students in its three branches (science, humanities, legal) from the eastern directorate of Khan Yunus governorate. The study sample consisted of 285 students that were chosen according to the stratified random method. The study concluded the following results that the most common sources of school pressure among the study sample were in the exams and curriculum pressures. The results also showed that female students are more exposed to school pressures than male students. The results indicated that there are no differences in the total score of scale of school stress attributed to the academic specialization and level of education of the head of the family except after the curriculum stresses. 
Rizk (2008) conducted a study entitled "the problems of secondary school students and their counseling needs". This research aims to identify the indicative needs of secondary school students through the course of the problems they suffer according to the fields. In addition, the significance of the differences in these problems is defined according to the variables of the academic class, gender and specialization. The results of the study showed that there are no statistically significant differences in these variables between male and female as well as between the scientific and literary specialties.

Al-Abideen (2013) conducted a study entitled "Negative Behavior Patterns and their Relationship to Academic Achievement among Secondary School Students in Khartoum State: A Field Study from the Teachers 'Point of View". The study aimed to know the patterns of negative behavior and its relationship to academic achievement of second stage students in the state of Khartoum from the point of view of teachers in the east unit of Khartoum (Al Baraari and Imtidaad Nasser). The study population consists of all supervisors and teachers of the secondary stage, and a random stratified sample consisting of 60 male and female teachers was chosen from a number of government schools consisting of five schools with a number of teachers of 120 teachers for the year 2012/2013. The study concluded that the degree of negative behavior patterns with high school students is high as the field of relationship between teachers occupied the primary rank among the fields of study with a relative weight of $48 \%$ and a weak prevalence rate. While there is a relationship between some members of common negative behavior patterns of high school students and their level of academic achievement from the teachers' point of view, the study also found that there were no statistically significant differences in the degree of prevalence of negative behavior patterns from the point of view of individuals with different demographic variables.

\section{Approach of the Study}

The current study adopts the descriptive analytical approach, which depends on the interpretation of the existing situation of the studied phenomenon by defining the circumstances and the dimensions associated with it, and describing the relationships between them with the aim of arriving at an accurate and integrated scientific description of the problem based on the facts associated with it. This approach goes beyond a process of describing the phenomenon, but it also includes analyzing, measuring and interpreting data to arrive at an accurate description and results of the phenomenon.

\section{Study Community}

In this study, the study population consisted of all students enrolled in the public secondary stage in Tafila Governorate for the academic year 2019/2020, and they numbered (2025) male and female students. 
INTERNATIONAL JOURNAL OF ACADEMIC RESEARCH IN PSYCHOLOGY

Vol. 7, No. 1, 2020, E-ISSN: 2312-1882 @ 2020 KWP

Table (1) shows their distribution according to the gender variable:

Table (1): Distribution of the study sample by sex

\begin{tabular}{|c|l|l|}
\hline Variable & Variable class & the number \\
\hline Sex & male & 909 \\
\cline { 2 - 3 } & female & 1116 \\
\hline & Total & 2025 \\
\hline
\end{tabular}

\section{Sample of the Study}

The study sample is divided into:

1. Exploratory sample: where the researcher chose a survey sample to experiment the study tools. It consisted of (35) male and female students.

2. The actual sample: The sample of the study consisted of (364) male and female students chosen in the random cluster method, which constituted (17.9\%) of the original study community. Table (2) shows distribution of study sample individuals by gender.

Table (2): Distribution of study sample individuals by gender

\begin{tabular}{|r|c|c|}
\hline Variable & Variable class & the number \\
\hline \multirow{2}{*}{ Gender } & male & 137 \\
\cline { 2 - 3 } & female & 227 \\
\hline
\end{tabular}

\section{Tools of the Study}

The researcher used the questionnaire as the most appropriate tools for scientific research that are consistent with the data of the study as a tool to collect the necessary information for this study. It is used to achieve the goals of the study; to obtain information and facts related to a specific reality. The researcher by referring to educational literature and previous studies used the questionnaire as a tool to collect data, to find out the impact of the tests on psychological problems of public high school students in Jordan. The researcher developed a questionnaire that includes three dimensions, namely:

- The first dimension: academic problems.

- The second dimension: behavioral problems.

- The third dimension: personal problems.

Validity of the study tool: The researcher has confirmed the validity of the study tool through:

The apparent validity of the tool:

The indications of apparent validity were verified by using the sincerity of the arbitrators, and by distributing the questionnaire in its primary form to (11) arbitrators from Jordanian university professors, and those who made some observations about it which the researcher took. In the light 
INTERNATIONAL JOURNAL OF ACADEMIC RESEARCH IN PSYCHOLOGY

Vol. 7, No. 1, 2020, E-ISSN: 2312-1882 @ 2020 KWP

of their amendments, their opinions, suggestions and amendments were taken into consideration, and the questionnaire was judged according to the following table (3)

Table (3): the name of questionnaire arbitrators

\begin{tabular}{|c|l|l|c|}
\hline $\begin{array}{c}\text { the } \\
\text { number }\end{array}$ & \multicolumn{1}{|c|}{ The name } & The destination & Nationality \\
\hline .1 & Prof. Abdul Hakim bin Abdullah & $\begin{array}{l}\text { University Sultan Zain Al } \\
\text { Abidin }\end{array}$ & Malaysian \\
\hline .2 & Dr. Najiha Abdul Wahid & $\begin{array}{l}\text { University Sultan Zain Al } \\
\text { Abidin }\end{array}$ & Malaysian \\
\hline .3 & Dr. Mohammed Al-Shafi & $\begin{array}{l}\text { University Sultan Zain Al } \\
\text { Abidin }\end{array}$ & Malaysian \\
\hline .4 & Prof. Suleiman Al-Hijaya & Tafila University & Jordanian \\
\hline .5 & Dr. Nizar Addomuury & Mutah University & Jordanian \\
\hline .6 & Dr. Mohammed Al-Khasoba & Tafila University & Jordanian \\
\hline .7 & Prof. Ahmad Odeh & Tafila University & Jordanian \\
\hline .8 & Dr. Muhammad Al-Quddot & Tafila University & Jordanian \\
\hline .9 & Dr. Abdullah Al-Qarara & Tafila University & Jordanian \\
\hline .10 & Dr. Atef El-Iyayada & $\begin{array}{l}\text { Arabic } \\
\text { supervisor }\end{array}$ & Jordanian \\
\hline .11 & $\begin{array}{l}\text { Dr. Khadija Suleiman } \quad \text { Al- } \\
\text { Zaghamim }\end{array}$ & $\begin{array}{l}\text { Teaching Curriculum } \\
\text { Supervisor / Ministry of } \\
\text { Education }\end{array}$ & Jordanian \\
\hline
\end{tabular}

Accordingly, the study tool (the questionnaire) was finalized.

\section{Validate the Internal Consistency of the Tool}

The validity of the questionnaire was verified by using the validity of the internal consistency to calculate the correlation between the degree of the paragraph and the total score on a survey sample of (35) students who were randomly chosen from within the community and were not included in the study sample.

First: The validated internal structure was used to identify psychological problems by calculating the Pearson correlation coefficient between the degree on the paragraph and the total degree. Tables (4) show the coefficients of correlation. 
INTERNATIONAL JOURNAL OF ACADEMIC RESEARCH IN PSYCHOLOGY

Vol. 7, No. 1, 2020, E-ISSN: 2312-1882 @ 2020 KWP

Table (4): the validity of the internal structure to identify psychological problems by calculating the Pearson correlation coefficient between the score on the vertebra and the total score $(n=35)$

\begin{tabular}{|c|c|c|c|}
\hline Paragraph & $\begin{array}{c}\text { Correlation } \\
\text { coefficient }\end{array}$ & Paragraph & $\begin{array}{c}\text { Correlation } \\
\text { coefficient }\end{array}$ \\
\hline 1 & .544 & 16 & .367 \\
\hline 2 & .579 & 17 & .341 \\
\hline 3 & .485 & 18 & .403 \\
\hline 4 & .410 & 19 & .314 \\
\hline 5 & .442 & 20 & .452 \\
\hline 6 & .431 & 21 & .400 \\
\hline 7 & .525 & 22 & .346 \\
\hline 8 & .391 & 23 & .451 \\
\hline 9 & .468 & 24 & .533 \\
\hline 10 & .661 & 25 & .319 \\
\hline 11 & .320 & 26 & .511 \\
\hline 12 & .437 & 27 & .426 \\
\hline 13 & .437 & 28 & .468 \\
\hline 14 & .339 & 29 & .498 \\
\hline 15 & .507 & 30 & .513 \\
\hline
\end{tabular}

Table (4) shows that good internal construction validity indicators were achieved for the questionnaire, where correlation coefficients ranged between (0.314-0.661).

Reliability of the study tool: The significance of the questionnaire stability was verified by using the Alpha Cronbach equation for internal consistency over the same exploratory sample $(n=35)$. Table (5) shows the stability of the resolution parameters

Table (5): Cronbach alpha coefficients for the internal consistency of the study instrument

\begin{tabular}{|c|c|}
\hline The dimension & $\begin{array}{c}\text { Stability } \\
\text { Coefficient }\end{array}$ \\
\hline Study problems & .86 \\
\hline Behavioral problems & .83 \\
\hline Personal problems & .76 \\
\hline $\begin{array}{c}\text { The total score to measure } \\
\text { psychological problems }\end{array}$ & .88 \\
\hline
\end{tabular}

Table (5) clarifies the stability coefficients of the study tool (the questionnaire), and the stability coefficients of the study tool ranged between $(0.76-0.86)$, and these values of stability are appropriate. 


\section{Statistical Treatments}

To achieve the goals of the study and to analyze the collected data, many appropriate statistical methods were used using the Statistical Package for Social Sciences, which is denoted by the abbreviation of the symbol (SPSS).

After the data was encoded and entered into the computer, and to determine the length of the pentagonal scale (the lower and upper bounds) cells used in the study axes, the response to the questionnaire is done according to the Pent-Likert scale (very high, high, medium, simple, never affects), and the grades are respectively given $(5,4,3,2,1)$. The degree of approval is judged based on the following criterion

\begin{tabular}{|c|c|}
\hline SMA & $\begin{array}{c}\text { Level relative to the } \\
\text { arithmetic mean }\end{array}$ \\
\hline $1-2.33$ & Low \\
\hline $2.34-3.67$ & Average \\
\hline And above 3.68 & High \\
\hline
\end{tabular}

\section{Discussing the Result}

Results of the first question: What is the level of psychological problems among public high school students?

To answer the first question, the arithmetic averages and the standard deviations for paragraphs and table (6) have been calculated that shows:

Table (6): Arithmetic averages and standard deviations for the total score, and the paragraphs on the scale of psychological problems for public high school students in Tafila Governorate

\begin{tabular}{|c|c|c|c|c|c|}
\hline $\begin{array}{c}\text { the } \\
\text { number }\end{array}$ & Paragraph & $\begin{array}{c}\text { The average } \\
\text { Arithmetic }\end{array}$ & $\begin{array}{c}\text { The normative } \\
\text { deviation }\end{array}$ & Rank & the level \\
\hline 19 & $\begin{array}{c}\text { I feel sad about the } \\
\text { low scores on the } \\
\text { tests }\end{array}$ & 4.36 & .91 & 1 & High \\
\hline 2 & $\begin{array}{c}\text { I accept and respect } \\
\text { all teachers }\end{array}$ & 4.17 & .93 & 2 & High \\
\hline 17 & $\begin{array}{c}\text { I think the gloom } \\
\text { ends when the tests } \\
\text { are over }\end{array}$ & 4.11 & .90 & 3 & High \\
\hline 8 & $\begin{array}{c}\text { I think the curriculum } \\
\text { is super difficult }\end{array}$ & 3.98 & .91 & 4 & High \\
\hline 6 & $\begin{array}{c}\text { I feel upset about the } \\
\text { negative behaviors } \\
\text { that students take } \\
\text { during classes }\end{array}$ & 3.79 & .91 & 5 & High \\
\hline $\begin{array}{c}\text { I understand the } \\
\text { school laws and } \\
\text { regulations and }\end{array}$ & 3.69 & .89 & 6 & \\
\hline
\end{tabular}


INTERNATIONAL JOURNAL OF ACADEMIC RESEARCH IN PSYCHOLOGY

Vol. 7, No. 1, 2020, E-ISSN: 2312-1882 @ 2020 KWP

\begin{tabular}{|c|c|c|c|c|c|}
\hline & $\begin{array}{c}\text { disciplined } \\
\text { implementation }\end{array}$ & & & & \\
\hline 7 & $\begin{array}{l}\text { I participate in } \\
\text { extracurricular } \\
\text { activities }\end{array}$ & 3.68 & .85 & 7 & High \\
\hline 1 & $\begin{array}{l}\text { I feel I have the } \\
\text { decisive desire to } \\
\text { learn }\end{array}$ & 3.57 & .94 & 8 & Average \\
\hline 9 & $\begin{array}{l}\text { I constantly do } \\
\text { homework }\end{array}$ & 3.55 & .94 & 9 & Average \\
\hline 10 & $\begin{array}{c}\text { The teacher neglects } \\
\text { my thoughts and } \\
\text { contributions }\end{array}$ & 3.55 & .94 & 10 & Average \\
\hline 30 & $\begin{array}{c}\text { I communicate with } \\
\text { teachers outside of } \\
\text { school }\end{array}$ & 3.55 & .88 & 11 & Average \\
\hline 12 & $\begin{array}{c}\text { I miss feeling } \\
\text { psychological } \\
\text { comfort and } \\
\text { contentment in my } \\
\text { life }\end{array}$ & 3.54 & .97 & 12 & Average \\
\hline 13 & $\begin{array}{l}\text { I have a feeling of } \\
\text { depression at tests }\end{array}$ & 3.53 & .83 & 13 & Average \\
\hline 14 & $\begin{array}{c}\text { I suffer from } \\
\text { permanent struggle } \\
\text { with myself }\end{array}$ & 3.52 & .96 & 14 & Average \\
\hline 15 & $\begin{array}{l}\text { I feel tight and } \\
\text { restless when } \\
\text { submitting tests }\end{array}$ & 3.51 & .73 & 15 & Average \\
\hline 16 & $\begin{array}{l}\text { I am unable to } \\
\text { control my emotions } \\
\text { before the tests }\end{array}$ & 3.50 & .79 & 16 & Average \\
\hline 11 & $\begin{array}{l}\text { I am accused of } \\
\text { cheating on tests }\end{array}$ & 3.47 & .91 & 17 & Average \\
\hline 18 & $\begin{array}{l}\text { I feel that the tests } \\
\text { are useless }\end{array}$ & 3.45 & .81 & 18 & Average \\
\hline 4 & $\begin{array}{c}\text { I interact during class } \\
\text { sessions by } \\
\text { participating and } \\
\text { asking questions }\end{array}$ & 3.44 & .84 & 19 & Average \\
\hline 20 & I miss classes & 3.44 & .90 & 20 & Average \\
\hline 21 & $\begin{array}{l}\text { I make false excuses } \\
\text { to miss the tests }\end{array}$ & 3.42 & .99 & 21 & Average \\
\hline
\end{tabular}


INTERNATIONAL JOURNAL OF ACADEMIC RESEARCH IN PSYCHOLOGY

Vol. 7, No. 1, 2020, E-ISSN: 2312-1882 @ 2020 KWP

\begin{tabular}{|c|c|c|c|c|c|}
\hline 28 & $\begin{array}{c}\text { I'm scared of dealing } \\
\text { with others }\end{array}$ & 3.41 & .91 & 22 & Average \\
\hline 23 & $\begin{array}{c}\text { I feel uncomfortable } \\
\text { when the tests } \\
\text { approach }\end{array}$ & 3.40 & .93 & 23 & Average \\
\hline 3 & $\begin{array}{c}\text { I participate with my } \\
\text { classmates in the } \\
\text { study }\end{array}$ & 3.39 & .93 & 24 & Average \\
\hline 25 & $\begin{array}{l}\text { I constantly feel } \\
\text { sorrow and sadness }\end{array}$ & 3.37 & .86 & 25 & Average \\
\hline 26 & $\begin{array}{l}\text { I suffer from health } \\
\text { problems at the time } \\
\text { of the tests }\end{array}$ & 3.37 & .94 & 26 & Average \\
\hline 27 & $\begin{array}{c}\text { I prefer studying with } \\
\text { colleagues }\end{array}$ & 3.36 & .87 & 27 & Average \\
\hline 5 & $\begin{array}{l}\text { I prefer studying } \\
\text { books outside the } \\
\text { curriculum }\end{array}$ & 3.34 & .94 & 28 & Average \\
\hline 29 & $\begin{array}{l}\text { I stay making new } \\
\text { friends with great } \\
\text { difficulty }\end{array}$ & 3.32 & 0.82 & 29 & Average \\
\hline 24 & $\begin{array}{l}\text { I do not have the } \\
\text { ability to talk about } \\
\text { my psychological } \\
\text { problems }\end{array}$ & 3.27 & 0.81 & 30 & Average \\
\hline & Total marks & 3.57 & 0.28 & --- & Average \\
\hline
\end{tabular}

It is noted from Table (6) that the arithmetic mean of psychological problems among students in the public secondary stage in Tafila Governorate came with an average arithmetic average (3.57) and a standard deviation (0.28). This result is consistent with the study of (Rabaabiha, 2015) whose results showed an average level of obstacles related to academic achievement, as well as a study of (Sherab and Wadi, 2015) whose results summarized that the most common sources of school stress to the study sample were examinations and curriculum pressures.

Results of the second question: What is the effect of the tests on the psychological problems of public high school students in Tafila Governorate?

To answer the question, a simple regression analysis was used and Table (7) shows that: 
INTERNATIONAL JOURNAL OF ACADEMIC RESEARCH IN PSYCHOLOGY

Vol. 7, No. 1, 2020, E-ISSN: 2312-1882 @ 2020 KWP

Table No. (7): Results of simple regression analysis to test the effect of tests on psychological problems among public high school students in the province of Tafila

\begin{tabular}{|l|l|l|l|l|l|l|l|}
\hline $\begin{array}{l}\text { Independent } \\
\text { variable }\end{array}$ & $\begin{array}{l}\text { Correlation } \\
\text { coefficient } \\
\mathrm{R}\end{array}$ & $\begin{array}{l}\text { Determination } \\
\text { coefficient R2 }\end{array}$ & $\mathrm{B}$ & $\begin{array}{l}\text { Standard } \\
\text { error }\end{array}$ & Beta & $\begin{array}{l}\text { Computed t } \\
\text { value }\end{array}$ & $\begin{array}{l}\text { Significanc } \\
\text { e level t }\end{array}$ \\
\hline $\begin{array}{l}\text { Gradient } \\
\text { constant }\end{array}$ & & & .406 & .113 & & 3.602 & .000 \\
\hline $\begin{array}{l}\text { Psychological } \\
\text { problems }\end{array}$ & .851 & .706 & .905 & .032 & .844 & 24.158 & .000 \\
\hline
\end{tabular}

The values of the test ( $t$ ) are clear from the statistical results mentioned in Table (7). The tests had an effect on the psychological problems of public high school students in Tafila Governorate, in terms of the (Beta) coefficients, as they appear in the table, and in terms of the rise in the calculated (t) values (24.158) from their tabular value at the significance level $(\alpha \leq 0.05)$. The variable of psychological problems explained (70.6\%) of the total variance in the tests for public high school students in Tafila Governorate.

The study considers that the emergence of the impact of the tests on psychological problems of public high school students is a tangible result in the societal reality, as secondary tests cause confusion that leads to psychological problems. The secondary stage is often considered a fateful stage that parents care about, which causes some pressure on their children, leading them to more psychological problems. This is consistent with the result of a study (Abdel-Lawi, 2012) that found an inverse relationship between psychological problems and academic achievement. It is also consistent with the study of (Shurrab and Wadi, 2015).

Results of the third question: Are there statistically significant differences at the level of significance $(\alpha<0.05)$ in the level of psychological problems due to (gender) variables?

The $T$ test was used for the independent samples to indicate the differences in the effect of the tests on psychological problems according to the gender variable. Table (8) shows that:

Table (8): Results of (T) test for independent samples to indicate differences in the effect of the tests on psychological problems according to the gender variable

\begin{tabular}{|c|c|c|c|c|c|c|c|}
\hline $\begin{array}{l}\text { The } \\
\text { dimension }\end{array}$ & Sex & $\begin{array}{l}\text { the } \\
\text { number }\end{array}$ & SMA & $\begin{array}{l}\text { standard } \\
\text { deviation }\end{array}$ & $\begin{array}{l}\text { Freedom } \\
\text { Degree }\end{array}$ & T value & Indication \\
\hline \multirow{2}{*}{$\begin{array}{l}\text { Study } \\
\text { problems }\end{array}$} & Male & 137 & 3.47 & .29 & & -3.531 & .000 \\
\hline & female & 227 & 3.54 & .27 & & & \\
\hline \multirow{2}{*}{$\begin{array}{l}\text { Behavioral } \\
\text { problems }\end{array}$} & Male & 137 & 3.47 & .21 & & -4.673 & .024 \\
\hline & female & 227 & 3.41 & .24 & & & \\
\hline \multirow{2}{*}{$\begin{array}{l}\text { Personal } \\
\text { problems }\end{array}$} & Male & 137 & 3.44 & .27 & & -2.432 & .000 \\
\hline & female & 227 & 3.48 & .27 & 362 & & \\
\hline
\end{tabular}


It is noted from Table (8) that there are statistically significant differences at the level of significance $(\alpha<0.05)$ in the impact of the tests on psychological problems according to the gender variable and in favor of females, where the values of $(T)=(-3.531)$ for study problems, and $(-4.673)$ for behavioral problems, and (-2.432) for personal problems, meaning that females are more affected by psychological problems.

The results of the study differ with the study of (Rizk, 2008), the study of (Rabaabiha, 2015) and the study of (Abdel-Lawi, 2012). This result is consistent with the study of (Zain El Abidin, 2013) and the study of (Sherrab \& Wadi, 2015).

\section{Conclusion}

Psychological problems are considered as a real concern for the students. Despite the fact that counseling centers and resources exist within the school campus, the psychological problems still appear among students during General Secondary Education Certificate Examinations in Jordan. This study showed that the psychological problems faced by these students include: the difficulty of retrieval, confusion, and anxiety. The researchers suggest that holding educational awareness sessions for students to guide them to avoid these problems during this Examinations so that these problems could not affect their motivation and achievements. Finally, future studies should include student life-styles and their correlation with the examinations. Therefore, the authors recommended further studies to explore this phenomenon in a more depth manner.

\section{References}

Abdel-Laawi, S. (2012). Psychological and behavioral problems among children of the first three years and their relationship to academic achievement (published Master Thesis) University of Mouloud Mameri, Algeria.

Al-Abidin, Z., Al-Sheikh, M. (2013). Patterns of negative behavior and their relationship to academic achievement for high school students in Khartoum State: a field study from the teachers 'point of view. Master Thesis, College of Education, University of Neelain, Sudan, 6(1), 134-143.

Al-Jolani, F. O. (1998). Diagnosis and treatment of psychological and social problems. Egypt: Radiation Technical Library and Press, 11(4), 133-136.

Amina, K. (2008). The problems of high school students and their counseling needs. Damascus University Journal, (24)2, 2210-2211.

El-Sherbiny, Z. (2002). Psychological problems among children. Cairo: Dar Al-Fikr Al-Arabi, 7(5), 232245.

Rabaabiha, H. A. (2015). Obstacles to academic achievement for public high school students (Tawjihi) from the viewpoint of successful and unsuccessful students and their parents. Jordanian Journal of Educational Sciences, 8(6), 111-114.

Rimawi, M. O. (2003). Developmental Psychology, Childhood and Adolescence. Amman: Dar AlMasirah, 20(2), 244-245.

Saadah, J., Zamil, M., and Ziyadah, I. (2004). The problems experienced by expatriate students at AnNajah National University during the uprising of Al-'aqsa. Journal of the Federation of Arab Universities, 6(40), 205-257.

Shabeer, W. S. (2007). Youth Problems and the Islamic Approach in Treating Them. Beirut: The Risalah Foundation. 


\section{INTERNATIONAL JOURNAL OF ACADEMIC RESEARCH IN PSYCHOLOGY}

Vol. 7, No. 1, 2020, E-ISSN: 2312-1882 @ 2020 KWP

Sharaab, A., and Wadi, A. (2015). Sources of school stress and its relationship to the general academic achievement of secondary school students in light of a number of variables. 10(8), 387-394.

Shreim, R. (2009). Adolescent Psychology. Amman: Dar Al Masirah for Publishing and Distribution, 9(2), 201-214. 